FDA legislation

\title{
FDA legislation
}

\section{Michael Givel}

\section{Time to shift US federal anti-tobacco advocacy tactics}

S ince 2004, a highly unusual annual spectacle has occurred with the introduction in Congress of similar US Food and Drug Administration (FDA) tobacco regulation bills. Often accompanied by considerable controversy and animosities, these FDA tobacco bills have always been supported by the tobacco giant Philip Morris along with numerous health groups including the Campaign for Tobacco-Free Kids, American Heart Association, American Lung Association, and American Cancer Society. At the centre of this controversy have been two important policy issues and questions. Firstly, why would a giant tobacco company actually campaign to be more stringently regulated? Secondly, given the history of tobacco industry disease, deception, and duplicity why would antitobacco advocates actually believe that this is in the best interest of public health and even public health advocacy?

The origins of this modern controversy began in 1996 when the FDA issued a final rule regulating tobacco as a drug and drug delivery device. ${ }^{1}$ This final rule would have greatly restricted sales and distribution of tobacco products and also created a national counter-marketing and youth access campaign. ${ }^{1}$ The industry mobilised against this rule on two fronts. Firstly, it filed a federal lawsuit in Greensboro, North Carolina to overturn the regulation. ${ }^{12}$ In 2000, the industry won this legal battle when the US Supreme Court ruled in a 5-4 decision that the FDA had no authority to regulate tobacco products as a drug and drug delivery device or engage in a national youth access enforcement effort. ${ }^{3}$

The second front, aggressively advanced by Philip Morris (and opposed by the rest of the tobacco industry) was a concerted effort to enact much weaker and alternative FDA regulation of tobacco. ${ }^{1}$ The goals of this effort, besides stopping a future FDA regulation regulating tobacco as a drug and drug delivery device, was to use the alternative FDA regulation to stem future damages in lawsuits, improve its corporate image, and solidify its adult tobacco market position (which is primarily why the other tobacco companies oppose this effort). ${ }^{1-6}$
But how has Philip Morris attempted to implement these multiple policy goals? One key element of this campaign has been "constructive engagement" with key health groups and advocates. ${ }^{156}$ The beginning of this highly unusual effort by Philip Morris began in November 2001 when secret negotiations, of which many health advocates were unaware, were initiated between Philip Morris and the Campaign for Tobacco-Free Kids. ${ }^{4-11}$ In 2003, after a temporary impasse, these secret negotiations were reconvened by US Senator Mike Dewine (Republican, Ohio). ${ }^{4}$ A compromise was eventually struck that led in 2004 to the introduction in the US Senate of an FDA tobacco regulation bill by Senators Edward Kennedy (Democrat, Massachusetts) and Mike Dewine (Republican, Ohio).

Vigorous insider and outsider advocacy should immediately occur to enact at the federal level strong, uncompromised, and already scientifically proved tobacco consumption reduction measures with no pre-emption

The 2004 Dewine-Kennedy bill, which was also vigorously supported by the American Heart Association, American Lung Association, and American Cancer Society, called for various cigarette risk reduction approaches such as disclosure of tobacco ingredients, banning misleading health claims, previous FDA approval for tobacco design and performance changes, and FDA approval of modified risk tobacco products. ${ }^{11}$ Despite these cigarette risk reduction goals, the bill also proposed banning all additives except menthol (which is contained in Marlboros), prohibited reducing nicotine levels to zero, and contained weak antiblack market provisions. ${ }^{1}$ Finally, this bill would have significantly pre-empted state and local governments from regulating product standards, pre-market approval, adulteration, misbranding, labelling registration, good manufacturing standards, increasing the minimum age of tobacco use above 18, and reduced risk products. ${ }^{1}$ The 2004 bill was later defeated in committee. ${ }^{1}$ The same FDA tobacco legislation was reintroduced in 2005 but did not pass. ${ }^{12}{ }^{13}$

In 2007, the latest version of the FDA bill introduced by Senators Edward Kennedy and John Cornyn (Republican, Texas) in the Senate and Henry Waxman (Democrat, California) and Tom Davis (Republican, Virginia) in the US House contained very similar cigarette risk reduction requirements and virtually the same strong federal pre-emption of state and local provisions as the 2004 and 2005 FDA tobacco regulation legislation. ${ }^{14-16}$ In addition, like 2004 and 2005, the bill proposed banning all additives except menthol and prohibited reducing nicotine levels to zero. ${ }^{14}{ }^{15}$ One new provision in the bill included an anti-tobacco smuggling section with weak tracking and labelling enforcement that can easily be circumvented with counterfeit labels and packaging, as has been done in the past. ${ }^{14}$ Another new provision called for larger and clearer warning labels. ${ }^{14}{ }^{15}$ However, this provision did not require graphic colour pictures of major diseases associated with smoking as is required in Canada and instead made this a discretionary requirement. ${ }^{14} 15$

These bills have numerous major problems in vigorously promoting public health. One significant problem in the reduced risks requirements for new tobacco products is that the bill makes it very difficult and expensive to introduce new tobacco products. In combination with allowing menthol as an additive these risk reduction provisions stabilise the current tobacco market favouring current brands including Philip Morris's Marlboro. ${ }^{17} 18$ Another significant problem with the bill is that it requires a scientifically unproved claim that removing ingredients will makes cigarettes "safer." There is currently little conclusive evidence on what ingredients are linked to particular morbidities and mortalities and at what level. ${ }^{19}$ In fact proponents have not shown any scientifically reviewed evidence at all as to how this bill would save any lives. Also, the requirement prohibiting nicotine reduction to zero could actually force smokers to smoke more and inhale more deeply. ${ }^{20}$

The bill also provides a significant litigation shield for the tobacco industry. ${ }^{21}$ This occurs because an FDA seal of approval on a product will be used as a defence against higher punitive damages in product liability and tort lawsuits. Many anti-tobacco advocates have also argued that federal pre-emption of stronger state and local laws in a variety of areas represents a significant danger to future state and local tobacco advocacy and regulatory efforts. Another concern with the legislation is that the FDA, 
which is a consumer protection agency, would be placed in an untenable role of approving a product that also causes significant disease and death. ${ }^{20}$ The bill also gives the tobacco industry numerous avenues to veto and delay any proposed change to tobacco products through legislative veto, judicial review, and administrative hearings. ${ }^{14}{ }^{15}$ Finally, the current bill does not place any regulatory restrictions on tobacco that is exported internationally. ${ }^{14} 15$

In the end, the current FDA legislation's major requirement of cigarette risk reduction provisions is occurring with no public health consensus that this will work. Evidently the major health organisations supporting this bill are either gambling or engaging in wishful thinking that this will be effective.

The bill has even farther reaching consequences than this. The Philip Morris approach of constructive engagement and alternative FDA regulation blocks further federal attempts for a long time to regulate tobacco as a drug or drug delivery device. This legislation, if enacted, undoubtedly would become the status quo in US federal tobacco legislation. The bill also is a clever revision of the 1954 industry "Frank Statement," because if consumers are concerned about their health they should now contact the FDA rather than the tobacco industry as was the claim by the industry in the past. In essence, in exchange for nebulous and dubious risk reduction, Philip Morris is being handed a new corporate public relations makeover, a new litigation defence strategy, and a new lobbying strategy.

The dynamics of how this bill came about through years of secret negotiations also raises serious concerns about the future of anti-tobacco advocacy at the federal level. The confluence of interests that has formed to support this compromise bill means it will have the health groups' "seal of approval." This seriously undermines present and future public health efforts to de-normalise the industry. De-normalisation has been a key argument and tactic for stronger tobacco control regulations and higher tobacco taxes on a variety of fronts. And the final bonanza that Philip Morris will obtain is a stable tobacco market for adults for years to come with severe disease and death continuing in one form or another.

It does appear master chess player Philip Morris is eight moves ahead of the health groups so far with this FDA bill. This situation is not, however, set in stone. I urge US readers of this article to contact their US health organisations and their federal representatives supporting the current FDA bill urging them to reverse their support immediately. Tell them that non-scientifically proved legislative compromises in the name of public health should not be made under any circumstances. As an alternative, vigorous insider and outsider advocacy should immediately occur to enact at the federal level strong, uncompromised, and already scientifically proved tobacco consumption reduction measures with no pre-emption. These internationally recognised measures should include higher tobacco taxes, effective Canadian-style warning labels, appropriate tobacco advertising and promotion restrictions, effective tobacco cessation campaigns, vigorous anti-tobacco counter-marketing efforts, and smoke-free tobacco restrictions in public places including workplaces. ${ }^{22}$

Tobacco Control 2007; 16:217-218.

doi: 10.1136/tc.2007.021931

Correspondence to: Dr Michael S Givel, Department of Political Science, University of Oklahoma, 455 West Lindsey, Room 205 Norman, OK 73019, USA; mgivel@ou.edu

\section{REFERENCES}

1 Givel M. Philip Morris' FDA gambit: good for public health? J Public Health Policy 2005;26:450-68.

2 Givel M, Glantz S. The 'Global Settlement' with the tobacco industry: 6 years later. Am J Public Health 2004;94:218-24.

3 FDA v Brown \& Williamson Tobacco Corp, et al. US Reporter. Vol 529: US Supreme Court, 2000:120.

4 Mullins B. How Philip Morris' tobacco foes tied the knot. Roll Call 2004.

5 McDaniel PA, Smith EA, Malone RE. Philip Morris's project sunrise: weakening tobacco control by working with it. Tob Control 2006;15:215-23
6 McDaniel PA, Malone RE. Understanding Philip Morris's pursuit of US government regulation of tobacco. Tob Control 2005; 14:193-200.

7 Campaign for Tobacco-Free Kids. Press Office Release. Public Health Groups Oppose Moving Tobacco Buyout Bill In House Absent Agreement to Prevent Linkage to Bad FDA Legislation. Washington, DC: American Cancer Society, American Heart Association, and Campaign for Tobacco-Free Kids, 2003

8 Campaign for Tobacco-Free Kids. Press Office Release. Public Health Groups Oppose Latest Senate Proposal on FDA Legislation. Washington, DC: American Lung Association, American Cancer Society, American Heart Association, and Campaign for Tobacco-Free Kids, 2003.

9 Campaign for Tobacco-Free Kids. Press Office Release. Tobacco Bill Negotiations Failed Due to Loopholes Sought By Tobacco Industry; Cigarette Ban Issue is a Red Herring. Washington, DC: Campaign for Tobacco-Free Kids, 2003.

10 Campaign for Tobacco-Free Kids. Press Office Release. Public Health Groups Remain Committed to Passing Tobacco Buyout and Meaningful FDA Tobacco Authority. Washington, DC: Campaign for Tobacco-Free Kids, 2003.

11 Campaign for Tobacco-Free Kids. Press Office Release. Public Health Groups Remain Committed to Passing Tobacco Buyout and Meaningful FDA Tobacco Authority. Washington, DC: American Lung Association, American Cancer Society, American Heart Association, and Campaign for Tobacco-Free Kids, 2004

12 Associated Press. Lawmakers renew push for tobacco regulation: under bill, FDA would regulate sales, marketing and advertising. MSNBC.com. Available at http://www.msnbc.msn.com/id/ 7224464/, accessed 18 May, 2007

13 Philip Morris. Legislation \& Regulation: FDA Regulation of Tobacco Products Philip Morris. Available at: http://www.philipmorrisusa.com/ en/legislation_regulation/fda/ regulation_tobacco_products.aspAccessed 18 May, $200 \overline{7}$

14 The Family Smoking Prevention and Tobacco Control Act; HR 1108. 2007.

15 The Family Smoking Prevention and Tobacco Control Act; S 625. 2007.

16 Campaign for Tobacco-Free Kids. Regulation of tobacco products: what FDA legislation would do. Washington, DC: Campaign for Tobacco-Free Kids, 2007.

17 Givel M. FDA legislation requires significant changes to curb cigarette use. US Senate Health, Education, Labor, and Pensions Committee, Washington, DC, 2007.

18 Blum A. The need for FDA regulation of tobacco products. Washington, DC: Senate Health, Education, Labor, and Pensions Committee, 2007.

19 Pankow J, Watanabe K, Toccalino P, et al. Calculated cancer risks for conventional and 'potentially reduced exposure product' cigarette. Cancer Epidemiol Biomarkers Prev 2007; 16:584-92

20 Bridges A. FDA chief: don't regulate tobacco. Associated Press, 7 March, 2007

21 Martin A. Trying again for a bill to limit tobacco ads. New York Times 16 February $2007 \mathrm{Cl}$.

22 World Health Organization. WHO framework convention on tobacco control (WHO FCTC). Geneva: WHO, 2003. 